\title{
Patient-Reported Quality of Life 3 Months after Breast Reconstruction
}

\author{
Adelaida Avino ${ }^{1,4}$, Daniela Elena Gheoca-Mutu ${ }^{2,4}$, Laura Raducu ${ }^{3,4^{*}}$, Sorin Andrei Nedelea ${ }^{5}$, Cristian Radu Jecan ${ }^{3,4}$, \\ Ioan Lascar ${ }^{3,6}$ \\ 'Doctoral School, "Carol Davila" University of Medicine and Pharmacy, Faculty of Medicine, \\ Discipline of Plastic and Reconstructive Surgery, Bucharest, Romania \\ 2Discipline of Anatomy, "Carol Davila" University of Medicine and Pharmacy, Faculty of Medicine, Bucharest, Romania \\ ${ }^{3}$ Discipline of Plastic and Reconstructive Surgery, Faculty of Medicine "Carol Davila" University of Medicine and Pharmacy, Bucharest, Romania \\ ${ }^{4}$ Department of Plastic and Reconstructive Surgery, "Prof. Dr. Agrippa Ionescu" Clinical Emergency Hospital, Bucharest, Romania \\ 5Department of Urology, "Prof. Dr. Agrippa Ionescu" Clinical Emergency Hospital, Bucharest, Romania \\ ${ }^{6}$ Department of Plastic and Reconstructive Surgery, Emergency Clinical Hospital, Bucharest, Romania
}

${ }^{*}$ Corresponding author: Laura Răducu, Lecturer, MD, PhD Department of Plastic and Reconstructive Surgery Clinical Emergency Hospital "Prof. Dr. Agrippa lonescu"

7 Ion Mincu, Bucharest, Romania E-mail: raducu.laura@yahoo.com

\section{Rezumat}

Calitatea vieții pacientelor la 3 luni după reconstrucția mamară

Introducere: Cancerul de sân este considerat a fi cea de-a doua cauză de deces la femei după cancerul pulmonar. Datorită unui progres remarcabil, tratamentele împotriva cancerului de sân au devenit mai eficiente şi mai puțin toxice. În plus, procedurile reconstructive după mastectomie au îmbunătățit semnificativ calitatea vieții, în special la femeile mai tinere. Obiectivul studiului nostru a fost de a evalua calitatea vieții pacientelor la 3 luni după reconstrucția de sân.

Metode:Am efectuat un studiu prospectiv pe 25 de paciente care au beneficiat de reconstrucție imediată sau întârziată a sânului după mastectomie. A fost distribuit un chestionar privind calitatea vieții şi răspunsurile au fost evaluate.

Rezultate: Pacienții din mediul rural au raportat că sănătatea lor, în general, a fost mult mai proastă decât acum un an. Pacienții cu carcinom ductal au raportat o limitare serioasă pentru activități viguroase, cum ar fi alergarea, ridicarea obiectelor grele, participarea la sporturi extenuante. 15 pacienți au declarat că starea lor generală de sănătate este bună, 8 foarte bună şi doar două femei au considerat-o excelentă.

Concluzii: Reconstrucția de sân după mastectomie are un impact asupra calității vieții pacientelor. Prin urmare, există necesară recunoaşterea şi evaluarea calității vieții după reconstrucție. 
Cuvinte cheie: cancer de sân, reconstrucție de sân, calitatea vieții

\begin{abstract}
Background: Breast cancer is considered to be the second major cause of cancer death in women after lung cancer. Due to a remarkable progress, the treatments against breast cancer became more efficient and less toxic. In addition, the reconstructive procedures after mastectomy have improved significantly the quality of life especially in younger women. The aim of the study was to evaluate the quality of life of patients 3 months after breast reconstruction.

Methods: We performed a prospective study on 25 female patients who underwent immediate or delayed reconstruction of the breast after mastectomy. A health-related quality of life questionnaire was distributed and the answers were evaluated.

Results: The patients from the rural area reported that their health in general was much worse than one year ago. The patients with ductal carcinoma reported a serious limitation for vigorous activities, such as running, lifting heavy objects, participating in strenuous sports. 15 patients declared that their general health is good, 8 very good and just two women considered it excellent. Conclusions: Breast reconstruction following mastectomy have an effect on the patient's quality of life. Therefore, there is an increased need to recognize and evaluate the quality of life after post reconstruction.
\end{abstract}

Key words: breast cancer, breast reconstruction, quality of life

\section{Introduction}

The malignant breast tumor is considered be one of the most frequent cancers in women worldwide, affecting more than 1.5 million women every year. A high survival rate depends on an early diagnosis and a good therapeutic management (1). The patients with genetic mutations - BRCA1, BRCA2 and TP53 - have an additional risk of developing breast cancer (2). Even if the cases of breastconserving surgery have an ascending trend, the majority of patients needs total mastectomy (3). Unfortunately, the mastectomy leads to a permanent and negative change to the aspect of the woman (4). It has a substantial impact on the quality of life of the patients. Recently, the reconstructive intervention of the breast became the last surgical step in the breast cancer management (3), improving the selfesteem and health-related quality of life (HR-QoL) (5).

In recent years, health status instruments were introduced to evaluate the modifications in the health status of patients (6). Generic and specific instruments for measuring the HR-QoL are presented in literature. The most common generic instruments are the ShortForm 36 Health Survey (SF-36) and EuroQoL5 Dimension Questionnaire (EQ-5D). They are designed to be relevant to a vast range of populations and interventions. Specific HRQoL measures were created to be applicable across a specific disease or treatment (5). A specific instrument used by the plastic surgeons is the BREAST-Q, developed to highlight information regarding HR-QoL and patient satisfaction related to breast surgery (7). Thus, BREAST-Q should be used to evaluate the impact and effectiveness of breast surgery from patient's view (8).

The aim of this analysis was to evaluate patient quality of life 3 months after breast reconstructive procedure using the generic instrument SF-36. 4 different surgical methods were performed: the deep inferior epigastric artery perforator (DIEP) flap, the latissimus dorsi (LD) flap with silicone implant, expander 
with secondary implant in 2 stages, and direct implant-based reconstruction.

\section{Material and Methods}

We conducted a retrospective study on 25 patients admitted to the Plastic Surgery, for breast reconstruction after mastectomy, during a period of 6 months (June 2020 - November 2020). We took into consideration the following criteria: gender (female patients), patients who underwent mastectomy for confirmed breast cancer, immediate or delayed reconstructions and providing responses to the HR-QoL questionnaire.

There were excluded from the study, the patients who did not have obtainable pathological data, those who presented local, postradiation lesions, or metastases, nonresponse to the HR-QoL questionnaire or inability to answer questionnaires due to language barriers. The statistical analysis was based on the surgical operating documents, medical letters and postoperative records. The database comprised demographic information, smoking history, age at the time of surgery, chemotherapy, radiotherapy, but also timing between mastectomy and breast reconstruction. The histopathological aspects of the tumor were registered. The marital status and the income were also noted. The different surgical techniques and post-operative complications were registered.

The data were centralized and processed in Microsoft Excel 2016. Statistical analysis was performed using IBM SPSS - Statistical Package for the Social Sciences version 25.

Most continuous variables had a nonnormal distribution (Smirnov-Kolmogorov test) therefore we used a non-parametric test (Mann-Whitney) for comparisons between two groups, and Kruskal-Wallis test for comparisons between more than two groups.

The relationships between the continuous variables were analyzed by the Spearman's Rho correlation coefficient and were expressed by the correlation coefficient and the $p$ value ( $p<0.05$ was considered statistically significant in all analyzes). Because the non-normality of continuous variables, data is presented as median and range.

\section{Results}

Twenty-five cases of immediate or delayed reconstructions of the breast following mastectomy were performed throughout the period of the research. The median age at mastectomy was 44.36 years (range: $31-59$ ). The median time between mastectomy and breast reconstruction was determined - 20.76 (range: 0-84, 0 was considered for immediate breast reconstruction). From all the patients, 16 were from an urban area and 9 were smokers. Ductal carcinoma was found in 19 cases, 5 patients with lobular carcinomas, and other types of cancer in one case. Axillary lymph node dissection was performed for all patients, lymph nodes being invaded in 4 cases. 24 women received neoadjuvant chemotherapy, 14 patients underwent radiotherapy and 18 endocrine therapy. Unilateral breast reconstruction was performed in 21 patients. Latissimus dorsi flap with silicone implant was used for 9 patients, 4 individuals had autologous tissue reconstruction with DIEP free flap, 7 cases the reconstruction was perform just with silicone implant and the remaining underwent tissue expander implant following delayed implant breast reconstruction. The duration of hospitalization was strongly associated with the age of the patients, younger patients stayed fewer days $\mathrm{s}$ (Spearman's rho, $p=0.035$ ), the median duration being 9.48 (range: 5-20), but it was also associated with the type of reconstruction (Kruskal-Wallis Test, $\mathrm{p}=0.028$ ).

In our study, the HR-QoL was evaluated using the SF-36 questionnaire. In order to discover the parameters that affect the indicators of the QoL, we took into consideration the correlations between several variables, such as residence area, smoking history, histological type, adjuvant therapies, types of breast reconstruction, marital status and education. Only the statistically-significant correlations are shown in this manuscript.

Regarding the residence area, the group 
from the rural area reported that their health in general was much worse than one year ago, being statistically significantly higher that the women from the urban area (Mann-Whitney Test, $\mathrm{p}=0.049$; with the mean rank 16.83). The patients with ductal carcinoma reported a serious limitation for vigorous activities, such as running, lifting heavy objects, participating in strenuous sports (Mann-Whitney Test, $\mathrm{p}=0.03$, with a mean rank of 10.92 ). We found no statistically-significant variance between the groups regarding smoking history and adjuvant therapies (Mann-Whitney Test, $\mathrm{p}>$ 0.05). Using Kruskal-Wallis Test we revealed that the distribution of the physical health problems during the past 4 weeks, were statistically-significant across the same type of breast reconstruction $(\mathrm{p}<0.05)$. Regarding the emotional health problems, during the past 4 weeks, there was no statisticallysignificant contrast between the groups (Kruskal-Wallis Test, $\mathrm{p}>0.05$ ).

\section{Discussions}

Breast cancer treatment is based on surgical excision of primary breast cancer by either lumpectomy or mastectomy before the onset of local symptoms. Even if the patients can undergo lumpectomy, most of them still require mastectomy to reduce to minimum the risk of recurrence (9), a decision that may be influenced by demographic factors such as patient age, race, education, facility, residence area (10). The plastic surgeons, all over the world, are trying to create new breast following mastectomy, improving in this way the QoL (11, 12). The rate of the reconstructive procedures has increased from $11.6 \%$ in early 1998 (9) to about $43.3 \%$ in late 2014 (10). It is considered that the breast reconstruction has a positive effect on women's psychological health, selfesteem, body image and social adaptation (13). Currently, there are no guidelines on selecting the best reconstruction method for each individual patient (5).

In our study, six patients underwent immediate breast reconstruction with implants or expander. For one patient the intervention was bilateral. Five women were from urban area. The duration of hospitalization ranged between 5 to 9 days. Van Bommel et al. (2020) published a study on 445 patients showing a significantly better HR-QoL on the psychosocial and sexual status, but also on the physical well-being of the patients with immediate breast reconstruction (14).

We performed latissimus dorsi flap with silicone implant (Fig. 1) for 9 patients, from whom 5 were urban area and 8 had ductal carcinoma. The reconstruction was indicated after at least five months after mastectomy, only two patients presented after 84 months. The youngest patient had 31 years and she presented 21 invaded lymph nodes.

Delay breast reconstruction with implants was used for 7 patients, 8 to 24 months after mastectomy. Hospital stay varied from 5 to 10 days. The length of postoperative hospitalization was 10 to 12 days for patients with DIEP

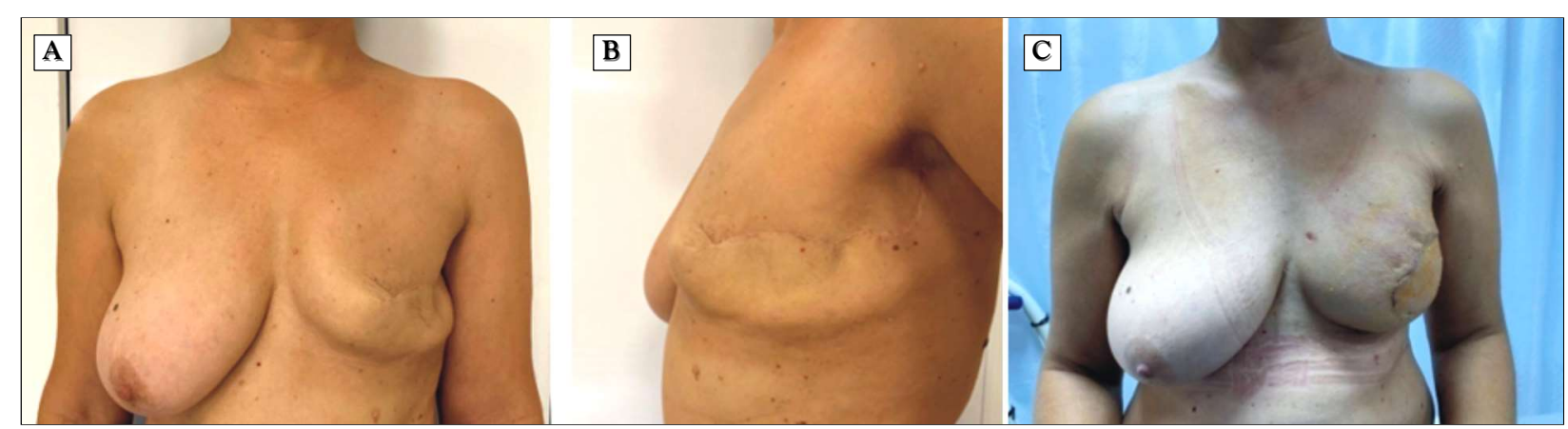

Figure 1. Patient with left mastectomy. (A,B) Post-mastectomy photos. (C) Outcome after breast reconstruction with latissimus dorsi flap and implant presented one month postoperatively 


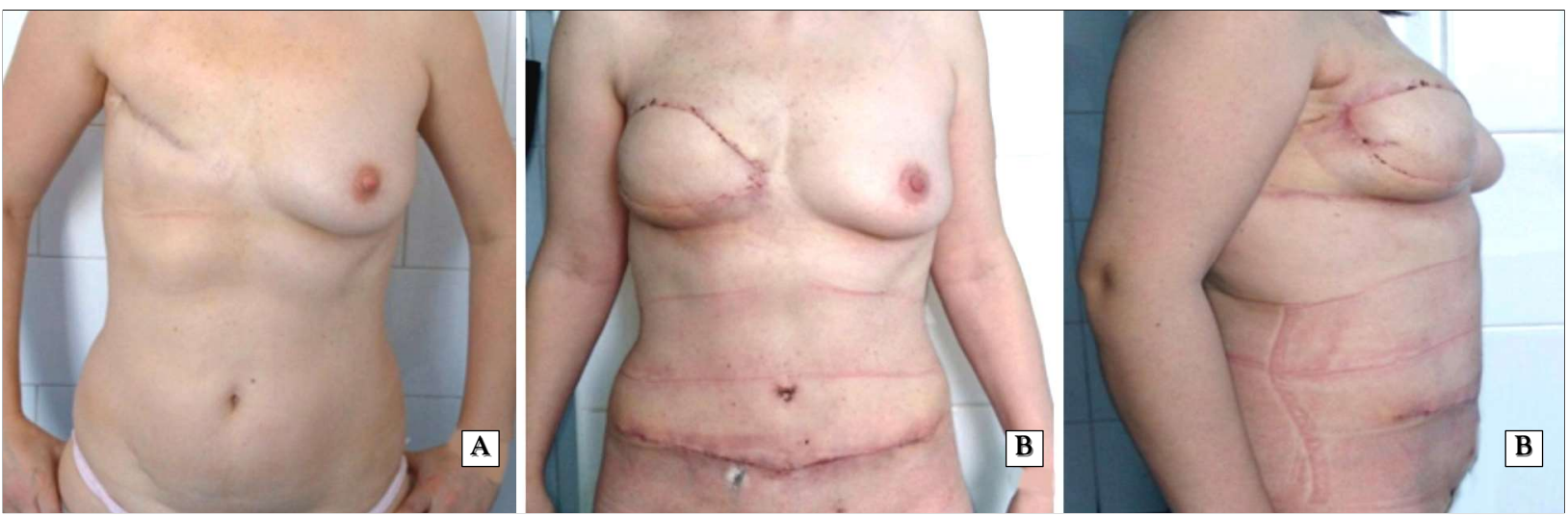

Figure 2. (A) Patient with previous right mastectomy. (B) Outcome after delayed breast reconstruction with DIEP flap shown three months postoperatively

flap (Fig. 2). Yueh et al. (2010) highlighted that patients who underwent reconstruction with DIEP flap are more likely to have a higher overall satisfaction compared to those who underwent any other type of breast reconstruction (15). Frey et al. (2017) presented a study on 116 patients, evaluating the length of stay after breast reconstruction. They had an average postoperative length of inpatient hospital stay in overall patient group of 4.16 days (16). Even if in our study the mean duration was 9.48, it did not modify the QoF of our patients.

The patients from the rural area reported that their health in general was much worse than one year ago, being unable to do all their daily activities. But in the same time, the reports regarding the emotional health and social activities were good. The study of Bhat et al. (2020) highlights the fact that patients from rural area have a reduce access to breast cancer care and reconstruction (17). Fortunately, in our clinic 9 from 25 women were from rural area. We consider that all patients desiring breast reconstruction after mastectomy should have the possibility to the surgical option of choice, given that they are appropriate candidates for that type of reconstruction.

Regarding the histological type the patients with ductal carcinoma reported a serious limitation for vigorous activities, such as running, lifting heavy objects, participating in strenuous sports, because of the adjuvant therapies they have done prior the breast reconstruction. The study made by Binotto et al. (2020) demonstrated that HR-QoL is negatively affected during chemotherapy (18). Mokhatri-Hesari et al. (2020) suggested that physical activity and psycho-social interventions proved to be effective and the quality of life in breast cancer patients improved greatly during recent years (19).

From all the patients, 15 patients declared that their general health is good, 8 very good and just two women considered it excellent. Concerning the bodily pain, 10 patients did not have any pain in the last 4 weeks, 7 reported moderate pain, 7 were with very mild or mild pain and just one with severe pain. A study made by Azad et al. (2020) on 591 patients indicated that the pain scores were highest at discharge. The results improved, but they did not reach preoperative pain scores, at 30-day follow-up. Moreover they suggested that younger patients may present a greater emotional distress and postoperative pain due to the diagnosis of breast cancer which is considered a threat to their quality of life and vitality $(20,21)$.

We want to specify one of the most important limitations of the study such as a small number of patients included due to the fact that the majority of breast reconstructions were postponed for 2021, as a consequence of the COVID19 pandemic.

Future directions of analysis into health- 
related quality of life will focus on discovering which type of breast reconstruction offer the best QoL. Furthermore, longer term follow-up will define also the aesthetic outcomes.

\section{Conclusions}

Nowadays, most women diagnosed with breast cancer survive. It is mandatory that a multidisciplinary team form by breast surgeons, plastic surgeons and a psychologist focus on identifying long-term implications of mastectomy and reconstruction. Breast reconstruction following mastectomy have an impact on the patient's quality of life. Therefore, there is an increased need to recognize and evaluate the quality of life after 3 months, 6 months and 1 year post reconstruction.

\section{Conflict of Interest}

The authors declare no conflict of interest.

\section{Ethics Approval}

Local ethical agreement and informed consent of the patient were obtained.

\section{References}

1. Sun YS, Zhao Z, Yang ZN, Xu F, Lu HJ, Zhu ZY et al. Risk Factors and Preventions of Breast Cancer. Int J Biol Sci. 2017; 13(11):1387-1397.

2. Somogyi RB, Ziolkowski N, Osman F, Ginty A, Brown M. Breast reconstruction: Updated overview for primary care physicians. Can Fam Physician. 2018;64(6):424-432.

3. Qin Q, Tan Q, Lian B, Mo Q, Huang Z, Wei C. Postoperative outcomes of breast reconstruction after mastectomy: A retrospective study. Medicine (Baltimore). 2018; 97(5):e9766.

4. Koçan S, Gürsoy A. Body Image of Women with Breast Cancer After Mastectomy: A Qualitative Research. J Breast Health. 2016; 12(4):145-150.

5. Thorarinsson A, Fröjd V, Kölby L, Ljungdal J, Taft C, Mark H. Long-Term Health-Related Quality of Life after Breast Reconstruction: Comparing 4 Different Methods of Reconstruction. Plast Reconstr Surg Glob Open. 2017;21;5(6):e1316.

6. Sajid MS, Tonsi A, Baig MK. Health-related quality of life measurement. Int J Health Care Qual Assur. 2008;21(4):365-73

7. Liu LQ, Branford OA, Mehigan S. BREAST-Q Measurement of the Patient Perspective in Oncoplastic Breast Surgery: A Systematic Review. Plast Reconstr Surg Glob Open. 2018;7;6(8):e1904.

8. Pusic AL, Klassen AF, Scott AM, Klok JA, Cordeiro PG, Cano SJ. Development of a new patient-reported outcome measure for breast surgery: the BREAST-Q. Plast Reconstr Surg. 2009;124(2): 345-353.

9. Zehra S, Doyle F, Barry M, Walsh S, Kell MR. Health-related quality of life following breast reconstruction compared to total mastectomy and breastconserving surgery among breast cancer survivors: a systematic review and meta-analysis. Breast Cancer. 2020;27(4):534-566.

10. Vidt ME, Potochny J, Dodge D, Green M, Sturgeon K, Kass R et al. The influence of mastectomy and reconstruction on residual upper limb function in breast cancer survivors. Breast Cancer Res Treat. 2020;182: $531-541$.

11. McGuire KP, Santillan AA, Kaur P, Meade T, Parbhoo J, Mathias M, et al. Are mastectomies on the rise? A 13-year trend analysis of the selection of mastectomy versus breast conservation therapy in 5865 patients. Ann Surg Oncol. 2009;16:2682-2690.

12. Finck C, Barradas S, Zenger Z, Hinz A. Quality of life in breast cancer patients: Associations with optimism and social support. Int J Clin Health Psychol. 2018;18(1):27-34.

13. Stein MJ, Karir A, Arnaout A, Roberts A, Cordeiro E, Zhang T et al. Qualityof-Life and Surgical Outcomes for Breast Cancer Patients Treated with Therapeutic Reduction Mammoplasty Versus Mastectomy with Immediate Reconstruction. Ann Surg Oncol. 2020;27(11):4502-4512.

14. Van Bommel ACM, De Ligt KM, Schreuder K, Maduro JH, Van Dalen T, Vrancken Peeters MTFD et al. The added value of immediate breast reconstruction to health-related quality of life of breast cancer patients. Eur $\mathrm{J}$ Surg Oncol. 2020;46(10 Pt A):1848-1853.

15. Yueh JH, Slavin SA, Adesiyun T, Nyame TT, Gautam S, Morris DJ et al. Patient satisfaction in postmastectomy breast reconstruction: a comparative evaluation of DIEP, TRAM, latissimus flap, and implant techniques. Plast Reconstr Surg. 2010;125(6):1585-1595

16. Frey JD, Salibian AA, Karp NS, Choi M. Examining Length of Hospital Stay after Microsurgical Breast Reconstruction: Evaluation in a Case-Control Study. Plast Reconstr Surg Glob Open. 2017;28; 5(12):e1588.

17. Bhat B, Heiman AJ, Talwar AA, Dunne M, Amanjee K, Ricci JA. Access to Breast Cancer Treatment and Reconstruction in Rural Populations: Do Women Have a Choice? J Surg Res. 2020;254: 223-231.

18. Binotto M, Reinert T, Werutsky G, Zaffaroni F, Schwartsmann G. Healthrelated quality of life before and during chemotherapy in patients with early-stage breast cancer. Ecancermedicalscience. 2020:14:1007.

19. Mokhatri-Hesari P, Montazeri A. Health-related quality of life in breast cancer patients: review of reviews from 2008 to 2018. Health Qual Life Outcomes. 2020;18(1):338.

20. Azad AD, Bozkurt S, Wheeler AJ, Curtin C, Wagner TH, Hernandez-Boussard T. Acute pain after breast surgery and reconstruction: A two-institution study of surgical factors influencing short-term pain outcomes. J Surg Oncol. 2020 Jun 20;10.1002/jso.26070. Online ahead of print.

21. Avino A, Răducu L, Brîndușe LA, Jecan CR, Lascăr I. Timing between Breast Reconstruction and Oncologic Mastectomy-One Center Experience. Medicina (Kaunas). 2020; 56(2):86. 